\begin{tabular}{|l|l|}
\hline Postprint Version & 1.0 \\
\hline Journal website & $\underline{\text { http://linkinghub.elsevier.com/retrieve/pii/S0168-8510(10)00173-9 }}$ \\
\hline Pubmed link & $\underline{\text { http://www.ncbi.nlm.nih.gov/pubmed/20619921 }}$ \\
\hline DOI & $10.1016 / \mathrm{j}$. healthpol.2010.05.019 \\
\hline
\end{tabular}

This is a NIVEL certified Post Print, more info at http://www.nivel.eu

\title{
The potential of legislation on organ donation to increase the supply of donor organs
}

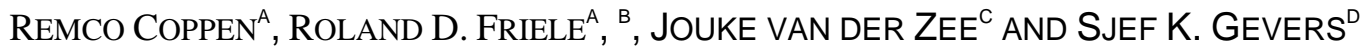 \\ ${ }^{a}$ NIVEL, Netherlands Institute for Health Services Research, PO Box 1568, 3500 BN Utrecht, The \\ Netherlands \\ ${ }^{\mathrm{b}}$ Tranzo (Scientific Centre for Transformation in Care and Welfare), Tilburg University, PO Box 90153, \\ 5000 LE Tilburg, The Netherlands \\ ${ }^{\mathrm{c}}$ Faculty of Health, Medical, and Life Sciences, Department of International Health, Maastricht University, \\ PO Box 616, 6200 MD Maastricht, The Netherlands \\ d Department of Social Medicine, Health Law Section, Academic Medical Center/University of Amsterdam, \\ PO Box 22660, 1100 DD Amsterdam, The Netherlands
}

\begin{abstract}
Objectives: The aim of this paper is to assess the possibilities to adapt the 1998 Dutch Organ Donation Act, taking account of fundamental principles such as the right to physical integrity, equitable access to and equal availability of care, and the non-commerciality principle, with a view to increasing the organ supply. Methods: In 2008 the Dutch Taskforce on Organ Donation presented several proposals to amend the Act and to increase the supply of organs. This paper describes the proposals to amend the Act and evaluates them by assessing their intrinsic adherence to basic principles and the available evidence that these proposals will indeed increase the organ supply. Results: Several proposals could constitute an infringement of fundamental principles of the Act. Moreover, evidence for their impact on the organ supply is lacking. Changing the consent system is possible, as this would not incur legal objections. There are diverging views regarding the impact of consent systems on the organ supply. Conclusions: The scope for changing the Act and its impact on organ procurement is at best limited. Relying on legislation alone will possibly not bring much relief, whereas additional policy measures may be more successful.
\end{abstract}

\section{INTRODUCTION}

During the past decades, Western-European countries have developed and implemented legislation on organ donation. Such legislation has various objectives; protecting the rights of the donor and other directly involved persons, supporting the supply of donor organs by encouraging donation, and efficient use of organs. It seeks to prevent organ trafficking and financial gain from organ donation, to guarantee a transparent and fair allocation of organs, and to provide legal certainty.

These objectives are based on a number of fundamental (legal) principles that take into account the interests of and provide legal certainty to patients, their next of kin, and medical staff. Principles such as the right to physical integrity, the prohibition of trade in human tissues (non-commerciality principle) and equitable access to and equal availability of care are laid down in international human rights documents, e.g. the Convention on Human Rights and Biomedicine (the Convention). On the one hand these principles 
leave room for interpretation, and countries are, at least to some extent, free as to how they incorporate them into their national legislation. On the other hand citizens may seek to derive rights from these principles and countries should ensure that their legislation is in accordance with these principles. When developing legislation on organ donation, governments, therefore, have to take into account these diverging interests and guarantee adherence to international legal documents.

The Netherlands, for example, enacted the Dutch Organ Donation Act in 1998. However, the persistent shortage of transplantable donor organs has given rise to heated political debate on this Act and has become a dominant issue in policy making for organ donation. This debate has resulted in several proposals to amend the Act. Likewise in other countries, such as the United Kingdom and the United States, the legal system for organ donation has recently been the subject of debate [1-4].

The question is to what extent legislation on organ donation can be amended with a view to increasing the supply of donor organs, taking into account the mentioned fundamental principles. In answering that question we consider the Dutch Organ Donation Act and the proposals to amend the Act in this article.

\section{BACKGROUND: THE DUTCH ORGAN DONATION ACT}

The Dutch Organ Donation Act (the Act) regulates the donation of organs and tissues for the medical treatment of other individuals [5]. The Act covers post-mortem donation and living donation. In this paper we focus on post-mortem donation.

The enactment of the legislation was preceded by public debate for more than 20 years. After all, the technical success of organ transplantation had given rise to several topical issues [6-8]. At first, the debate focused on the rights of the donor and on how to obtain consent. Because of a possible infringement of physical integrity, consent to organ removal was considered to be a necessary pre-condition.

At the end of the 1980s the organ procurement rates had declined, while the waiting lists for organ transplantation increased because of the growing possibilities for organ transplantation [8,9]. According to the Act's Explanatory Memorandum (1998), the following factors were considered to have caused this decline:

- A decrease in the confidence of the general public in organ donation procedures: Some people feared that their organs would be taken prior to death, which addressed the need for a brain death protocol [10]. Others were afraid that their organs would be donated without their consent [10-12]. In addition, it was not clear how organs were allocated and whether financial motives played a part in the allocation scheme.

- Lack of knowledge about the opportunity to donate: Despite the increased attention by the press towards issues related to organ transplantation, only a part of the population was acquainted with the opportunity to donate organs after death $[10,13]$

- Legal uncertainty about procedures and consent: For both the general public and the medical professions the legal implications of consent or refusal by relatives of the deceased were unclear $[14,15]$

The limits of physicians' authority to prepare and remove organs had not been defined.

The Dutch government concluded in the Explanatory Memorandum that the implementation of legislation and the creation of legal certainty and trust in organ donation procedures were necessary to help overcome these problems. The government considered safeguarding the rights of (potential) donors (i.e. providing legal certainty, but also ensuring compliance with fundamental principles such as protection of the physical integrity of the body, justice in the allocation of scarce organs, and the principle of non-commerciality) as a necessary condition for increasing the supply of donor organs. The legislator assumed that trust in the system was an essential condition for increasing the willingness to donate and would boost the supply of donor organs. These functions are reflected in the Act's objectives:

(1) to codify the law and to provide legal certainty, also with regard to the consent system

(2) to increase the supply of donor organs and tissues

(3) to ensure the fair allocation of donor organs and tissues

(4) to prevent commercialisation and organ trade.

These objectives are further elaborated in the Act's provisions. The most important provisions of the act are the consent system, based on explicit consent, the fact that allocation of organs only takes place based on medical criteria, and the prohibition of remuneration of donors (or their families) (see Box 1). 


\section{[Box 1]}

\section{THE PROPOSALS TO INCREASE THE SUPPLY OF DONOR ORGANS}

After the introduction of the Act in 1998, national donation rates dropped from 216 post-mortem donors in 1997 (13.8 donors per million inhabitants (PMI)) to its all time low of 165 donors in 1999 (10.4 donors PMI) $[16,17]$. At the same time the transplant waiting lists were still increasing and the shortage of donor organs had become a serious issue in both the political and the public arenas. In reaction, the government implemented additional policy measures to support the objective of the Act to increase the supply of donor organs; i.e. measures to increase the efficiency of the organ procurement process in hospitals and measures to inform the public on the positive aspects of organ donation.

In 2008, ten years after the introduction of the Act, 201 organ donors were procured (12.3 donors PMI) [18]. Several political parties and interest groups, such as the Dutch Kidney foundation and the Dutch Heart Foundation, held the opinion that the introduction of the Act and the implementation of the additional measures had apparently failed to have a positive impact on organ donation rates. The Dutch Kidney foundation therefore proposed the setting up of a master plan for organ donation. The Dutch Taskforce on Organ Donation took up this initiative and presented several proposals to amend the Act in order to increase the numbers of organ donors by June 2008 [19]. These proposals were aimed at adjusting the consent system, introducing non-medical criteria to the allocation system, and introducing financial incentives.

\subsection{Changing or adjusting the consent system}

The low consent rate for organ donation, either from potential donors themselves or next of kin, was regarded as one of the main bottlenecks behind the chronic shortage of transplantable donor organs [20]. Therefore, it was proposed to change or adjust the consent system.

\subsubsection{Presumed consent}

Irrespective of the consent system, most people do not register their wishes (whether consent or refusal), consequently the pool of potential donors in a presumed consent system far exceeds the pool of potential donors in an explicit consent system [21,22]. For this reason several Dutch interest groups and political parties suggested changing the current consent system, based on explicit consent, to a system based on presumed consent. However, changing to a presumed consent system was rejected by the Dutch House of Representatives. Some political parties feared that switching to a presumed consent system would lead to a decline in legal certainty and in the public's trust in the procurement system. They feared that this would harm organ procurement.

\subsubsection{Automatic consent}

To avoid a decline in legal certainty by losing the current consent registrations while retaining the possible advantages of a presumed consent system, a broad coalition of interest groups has suggested changing the position of unregistered individuals by introducing, what they call, "automatic consent registration". This would mean that all citizens not yet registered in the national registry, will receive a letter to inform them that if they do not explicitly refuse to be a donor they will automatically be registered as willing to donate in the national registry. To verify whether an individual really wants to be registered, this individual will receive a letter confirming his automatic registration.

On the whole, it was considered that automatic consent registration would seem to combine the advantages of presumed consent systems with the advantages of explicit consent systems. It still safeguards the rights of individual donors and their families and provides sufficient legal certainty; the advantage of explicit consent registrations. At the same time, this system might increase the donor pool; the advantage of introducing the default rule of presumed consent. It was considered that an increase of the donor pool could have a positive impact on the organ donation rates. Automatic consent registration was considered to be the best way to guarantee the registration of each Dutch citizen in the Dutch Donor Register. One could also have opted for a mandated choice system [23, 24]. However a mandated choice system was not seriously considered, because of difficulties with the implementation of such a system in The Netherlands.

\subsection{Introducing non-medical criteria to the allocation system to increase the donor organ supply}

To increase the number of transplantable donor organs the introduction of non-medical criteria to the allocation system has been proposed. 


\subsubsection{Reciprocity}

In The Netherlands there is a considerable difference between the number of people that say they are willing to donate their organs after death (69\%) [25] and the number of those who actually register their consent (23\%) [18]. Besides that, most people want to receive an organ when they need one. To make use of the willingness of people to donate their organs, to stimulate registration and to point out that those who want to receive an organ should normally be willing to donate an organ, Den Hartogh proposes the addition of reciprocity as a non-medical criterion to the allocation system [26]. He proposes that those who register as donors should be given priority if they are ever on a transplant waiting list. His underlying presumption is that creating incentives for becoming a donor would persuade citizens to register their consent in the national register.

\subsubsection{Living donor list exchange}

In the case of kidneys, one of the alternatives to the transplantation of a deceased individual's organ is to transplant a living individual's organ. For a successful living donation the medical match with the recipient is crucial. Sometimes, there is no medical match between the living donor and the intended recipient and there is no possibility for a cross-over transplantation (the exchange of an organ with another donorrecipient couple who experience the same problem) [27] According to the living donor list-exchange principle this patient (A) can pass on the organ, which was intended for him, to someone on the waiting list for a post-mortem organ (patient B). Patient B no longer needs to be on the waiting list for a post-mortem organ and, therefore, patient (A) gets extra priority in the allocation system to receive a post-mortem organ. Hence, the living donor list exchange introduces a new, non-medical, allocation criterion to increase the possibilities for transplantation. The underlying idea of this proposal is to stimulate living donation, even when there is no medical match between the acquainted living donor and the intended recipient.

\subsection{Introducing financial incentives to register as a donor or to donate organs}

The transplantation of a kidney saves lives and is considered to be more cost effective than dialysis [28]. Organ donors, therefore, reduce the financial burden of patients with organ failure. It has therefore been suggested that it is reasonable that citizens who show their intention to reduce this financial burden may also financially profit from this reduction. Several financial incentives to persuade citizens to actually become a living or a post-mortem donor, or to register as a donor have been proposed.

\subsubsection{Discount on health insurance by donor registration}

It is assumed that more registered organ donors will lead to more organ donations, thereby reducing the financial burden of patients with organ failure. It would be fair to return the money saved to the people who made this saving possible, the registered donors. Therefore, it has been proposed to give citizens who are registered as donors in the national register a discount on their health insurance.

\subsubsection{Reimbursement of funeral costs}

Another proposal was to reimburse the funeral costs for deceased individuals from whom an organ has been procured. It was proposed that the family should receive a part of the costs saved by the donation of the organ, to finance the funeral and to reward them for not refusing organ donation.

\subsubsection{Rewarding living donors}

Because post-mortem donor organs are scarce, living donation has become an important alternative treatment for patients with organ failure. To encourage people to donate an organ during their life it has been proposed, not only to pay the expenses for living donation, but also to financially reward living donors.

\section{DISCUSSION}

In this paragraph we will evaluate these proposals by assessing their intrinsic adherence to basic principles in health care and organ donation and the available evidence that the proposals will indeed increase the supply of donor organs and reduce waiting time for patients.

For the introduction of non-medical criteria in the allocation system, section 18(3) of the Dutch Organ Donation Act would have to be changed. This first raises the question whether such a change may possibly 
constitute an infringement of the Declaration (art. 5.5) and the Additional Protocol to the Convention on Human Rights and Biomedicine, on Transplantation of Organs and Tissues of Human Origin (the Protocol; art. 3). Both documents address the importance of equitable access to health care and stipulate that choices in health care should only be based on medical criteria. Does introducing reciprocity and the availability of a living donor as non-medical criteria detract from the fundamental principle that each patient should have the same opportunity to receive an organ? In The Netherlands, the right of equal access of patients to health facilities is embedded in the right to health and the equality principle laid down in the Constitution [29]. The equitable distribution of health services, safeguarded by the right of equal access, is one of the main principles of the Dutch health care system. To our view, compromising this principle by introducing nonmedical criteria may detract from the equal opportunity of patients to receive an organ, which may lead to a decrease in trust in the organ procurement system.

A second question is whether there is sufficient evidence that introducing non-medical criteria will increase the supply of donor organs. Ravelingien and Krom state that, on the contrary, introducing reciprocity to the allocation system could have some undesirable effects [30]. They argue that the more donors there are, the more people on a waiting list have priority, and the less advantage an individual gains by registering. They do not expect the supply of donor organs to increase. Apart from that, they state that the emphasis on personal responsibility within the practice of medicine is a new and still controversial matter of debate [30]. As some people are better equipped to exercise their own responsibility than others (others being mostly the least advantaged), introducing reciprocity into the allocation system may create longer waiting times for certain patient groups.

In the case of another example, the living donor list-exchange, Den Hartogh argues that although it is expected that the living donor list-exchange should increase the donor organ supply, it will tend to extend the waiting time for patients with rare blood groups or HLA-types who are not able to use the living donor list-exchange program [31]. He therefore, argues that the living donor list-exchange program disadvantages the least advantaged.

In conclusion, changing the Act in this respect may detract from the principle of equitable access to and equal availability of care. In both of our examples the equal opportunity for patient groups to receive an organ is at stake. Moreover, there is no clear evidence that the introduction will have an effect on the supply of donor organs. Introducing these criteria may even lead to some undesirable effects on the waiting times for (some) patients. Apart from that, Verzijden and Schothorst report that introducing reciprocity into the allocation of organs is not supported by the Dutch population [32]; this therefore, may lead to reduced trust in the system.

The introduction of financial incentives for donating an organ, e.g. reimbursing funeral costs or rewarding living donors, means that the non-commerciality principle of the Act would be abandoned and section 2 of the Act would have to be changed. Would such a change still be in line with art. 21 of the Convention and art. 21 of the Additional Protocol? These sections safeguard the principle that consent to the removal of organs may not be based on improper grounds or arise from financial need. By introducing financial incentives for donating organs, people with financial problems may feel compelled to donate organs in order to solve their monetary problems. Moreover, such an introduction could instigate trafficking in human beings for the purpose of the removal of organs. Safeguarding the non-commerciality principle is important for people's confidence in the organ procurement system [33].

In addition, it is not clear that financial incentives would lead to more organ donors; there are a lot of contradictory findings in this respect [34-39]. And again, the Dutch population do not support an organ procurement system with financial incentives [40].

This leads us to conclude that introducing financial incentives to donate organs will possibly meet with legal objections. Changing the Act as proposed may conflict with the non-commerciality principle, may diminish faith in the system, and there is no evidence available that this introduction will increase the donor organ supply.

Dutch health insurers are allowed to give a maximum of $10 \%$ discount on health insurance for collective contracts via employers, associations and member organizations. At the end of 2008 some health insurers did introduce a discount on health insurance for people who register in the national donor register; a variation on the discount on health insurance by donor registration. To receive this discount, it is not relevant which choice the insured has registered; those insured who register as non-donors are equally rewarded with a discount. In this case, it is not the human body and its parts, as such, but registering in the 
National Register that gives rise to financial gain. The introduction of this discount led to a political debate. Because the discount is only linked to registration, regardless of consent, refusal or leaving the decision to another individual, and is therefore achievable for anyone, the Dutch Minister of Health considered this discount to be in line with the Dutch Organ Donation Act and did not prohibit the discount. As the legal provisions seem to focus on financial gain by selling organs, whereas rewarding registration alone does not appear to be based on improper grounds or to arise from financial need, this measure does not seem to be in conflict with the non-commerciality principle. It remains unknown whether the measure has led to an increase of consent registrations or has had an effect on the supply of donor organs.

For the introduction of a system of automatic consent registration, sections 11(1) and 9(1) of the Act would have to be changed. Would such a change still be in line with the Protocol (art. 17)? According its explanatory report (no. 101-102), countries are free to implement a presumed or explicit consent system. As a matter of fact, many countries have implemented a consent system based on presumed consent [41], which to some extent corresponds with a system of automatic consent registration. The introduction of automatic consent registration does not lead to an infringement of relevant fundamental principles in health care and organ donation. Nonetheless, it remains unknown whether changing to another consent system will influence a sense of legal certainty regarding the protection of physical integrity and might jeopardise public trust in the procurement system [42].

Another important question is whether changing to another system will increase the supply of donor organs. There is, however, no clear answer to this question. In theory, there seem to be considerable differences in the efficiency of donor procurement between consent systems. But, there is a lot of debate as to whether in practice the efficiency of a presumed consent system prevails over the efficiency of an explicit consent system [21, 43, 46-51]. Gevers et al. report that because next of kin play an important role in obtaining consent for organ donation in each country, in reality consent systems are more similar than suggested by the explicit/presumed consent distinction [41,49,52].

Therefore we conclude that although the introduction of the latter system is possible from the point of view of fundamental principles, there is no evidence base to support the notion that changing the consent system will increase the supply of donor organs and reduce waiting time for patients.

\section{CONCLUSIONS}

The Dutch Organ Donation Act was originally designed to provide both legal certainty and trust in the procurement and distribution of organs. It was considered that more trust would increase the supply of donor organs. However, the implementation of the Act did not solve the organ shortage. Many considered the fact that explicit consent was a necessary pre-condition for organ donation to be a barrier for increasing the organ supply. Although providing legal certainty and ensuring compliance with fundamental principles was basically in line with the Act's function to increase the supply of donor organs, an area of tension became visible between both functions. This led to a reconsideration of the legislation in order to increase the supply of donor organs.

In order to boost the supply of donor organs, various proposals were made to amend the Act. We found several of the proposals to be at variance with the fundamental principles protected by the Dutch Organ Donation Act. Infringement of these principles may harm the trust of people in the procurement and distribution system of organ donation. The current opinion that in organ donation such infringements should be avoided is consistent among Western countries [33]. Apart from this, for most of the proposals evidence is lacking that they will lead to more donor organs. In fact, adverse effects may even be expected.

There is one exception to this finding. Many people consider that changing the consent system from explicit consent to presumed consent or automatic consent registration may help to increase the number of donations. Changing to another consent system will not incur legal objections, since it still leaves room for people to express their wishes and provides a guarantee for their right to physical integrity. The international literature provides diverging views regarding the impact of introducing a presumed consent system on increasing the supply of donor organs [21,43,46-51]. However, international comparative research linking procurement rates to consent systems, while controlling for differences in mortality rates, suggests the impact of such a change to be limited [41, 44,45,48,52].

This implies that the scope for changing the Dutch Organ Donation Act in order to increase the supply of donor organs is at best limited. More in general, it seems that relying on legal measures only to increase the number of donations will not bring much relief. Other ways, such as additional policy measures aimed at 
the procurement process in hospitals and at a sustained and comprehensive donor education policy, may be more successful in achieving this.

\section{CONFLICT OF INTEREST}

The authors declare that they have no conflict of interest.

\section{REFERENCES}

[1] S. Yadav, Lords decide against presumed consent for organ donation, British Medical Journal 337 (a698) (2008).

[2] UK Organ Donation Taskforce, The potential impact of an opt out system for organ donation in the UK (2008).

[3] J.F. Childress and C.T.E. Liverman, Organ donation: opportunities for action, National Academy of Sciences, Washington, DC (2006).

[4] J.M. DuBois, Response to commentaries on "Increasing Rates of Organ Donation", Journal of Clinical Ethics 1 (2009), pp. 41-43.

[5] Dutch Ministry of Health WaS, The Organ Donation Act: International Publication Series Health, Welfare and Sport nr. 3, Dutch Ministry of Health, Welfare, and Sports, The Hague (2000).

[6] F.Thd Charro, J.E.M. Akveld and D.J. Hessing, Systems of donor transfer, Health Policy 25 (1993), pp. 199-212.

[7] M. Defever, The policies of organ transplantation in Europe: issues and problems, Health Policy 16 (1990), pp. 95-103.

[8] H.D.C. Roscam Abbing, Organ donation, the legal framework 15, Health Policy 16 (1990), pp. 105-115.

[9] W. Kokkedee, Kidney procurement policies in the Eurotransplant region. 'Opting in' versus 'opting out', Social Science and Medicine 35 (2) (1992), pp. 177-182.

[10] Gezondheidsraad, Advies inzake: Algemene transplantatieproblematiek (Recommendation: general issues in transplantation), Gezondheidsraad, Den Haag (1987).

[11]A. Caplan, L. Siminoff, R. Arnold and B. Virgnig, Increasing organ and tissue donation: what are the obstacles, what are our options?, United States Public Health Service, Office of the Surgeon General, Washington, DC (1991).

[12] W. Kokkedee, Het tekort aan postmortale orgaandonaties: oorzaken en oplossingen in juridisch perspectief (The shortage of post mortal organ donations: causes and solutions from a legal point of view), Arnhem, Gouda Quint (1992).

[13] G.J.M.Wv. Thiel, G.J. Smalbraak-Schieven and B.M.Jd. Kanter-Loven, Het beslissysteem bij orgaandonatie: Rechten en plichten strijden om voorrang (The consent system for organ donation: rights and obligations compete for priority), Medisch Contact 48 (43) (1993), pp. 1339-1342.

[14] J.E.M. Akveld, Juridische aspecten van orgaandonatie (Legal aspects of organ donation). In: G. Kootstra, J.E.M. Akveld and D.J. Hessing, Editors, Orgaandonatie, een kwestie van bereidheid (Organ donation, a matter of obligingness), Koninklijke Vermande, Lelystad (1988).

[15] W.R. Vroom-Kastelein, Toestemming voor orgaandonatie: geen bezwaar? (Consent for organ donation: no objection?), Tijdschrift voor Gezondheidsrecht 3 (1986), pp. 154-163.

[16] Nederlandse Transplantatie Stichting, Jaarverslag 1999 (Annual Report 1999), Nederlandse Transplantatie Stichting, Leiden (2000).

[17] Nederlandse Transplantatie Stichting, Jaarverslag 2006 (Annual Report 2006), Nederlandse Transplantatie Stichting, Leiden (2007).

[18] Nederlandse Transplantatie Stichting, Jaarverslag 2008 (Annual Report 2008), Nederlandse Transplantatie Stichting, Leiden (2009).

[19] Coördinatiegroep Orgaandonatie, Masterplan orgaan donatie, de vrijblijvendheid voorbij (Masterplan organ donation, beyond volunteerism), Coördinatiegroep Orgaandonatie, Den Haag (2008).

[20] R.J. Ploeg, J. Niesing, M.H. Sieber-Rasch, L. Willems, K. Kranenburg and A. Geertsma, Shortage of donation despite an adequate number of donors: a professional attitude?, Transplantation 76 (6) (2003), pp. 948-955.

[21] H. Gäbel, Organ donor registers, Current Opinion in Organ Transplantation 11 (2006), pp. 187-193.

[22] E.J. Johnson and D.G. Goldstein, Defaults and donation decisions, Transplantation 78 (12) (2004), pp. $1713-1716$.

[23] P. Chouhan and H. Draper, Modified mandated choice for organ procurement, Journal of Medical Ethics 29 (2003), pp. 157-162.

[24] A. Spital, Mandated choice for organ donation: time to give it a try, Annals of Internal Medicine 125 (1) (1996), pp. 66-69. 
[25] European Commission, Special Eurobarometer: European and organ donation (2007).

[26] Gd. Hartogh, Gift of bijdrage?: over morele aspecten van orgaandonatie (Gift or contribution?: about moral aspects of organ donation), Rathenau Instituut, Den Haag (2003).

[27] L.W. Kranenburg, T. Visak, W. Weimar, W. Zuidema, Md. Klerk and M. Hilhorst et al., Starting a crossover kidney transplantation program in The Netherlands: ethical and psychological considerations, Transplantation 78 (2) (2004), pp. 194-197.

[28] Council of Europe, Meeting the organ shortage: current status and strategies for improvement of organ donation (1999).

[29] A.C. Hendriks, Gelijke toegang tot zorg - van ideaal naar recht (Equitable access to health care - from ideal to right), Tijdschrift voor Gezondheidsrecht 25 (special) (2001), pp. 55-64.

[30] A. Ravelingien and A. Krom, Earning points for moral behavior, International Journal of Applied Philosophy 19 (1) (2005), pp. 73-83.

[31] Gd. Hartogh, Trading with the waiting-list: the justice of living donor list exchange, Bioethics (2008)

[32] D. Verzijden and Y. Schothorst, Orgaandonatie: Alternatieve beslissystemen (Organ donation: alternative consent systems), Veldkamp, Amsterdam (2003).

[33] A. Caplan, B. Domínguez-Gil, R. Matesanz and C. Prior, Trafficking in organs, tissues and cells and trafficking in human beings for the purpose of the removal of organs: Joint Council of Europe/United National Study, Council of Europe/United Nations, Strasbourg (2009).

[34] J.R. Rodrigue, D.L. Cornell and R.J. Howard, Attitudes toward financial incentives. Donor autorization, and presumed consent among next-of-kin who consented vs. refused organ donation, Transplantation 81 (9) (2006), pp. 1249-1256.

[35] D. Mayrhofer-Reinhartshuber, A. Fitzgerald, G. Benetka and R. Fitzgerald, Effects of financial incentives on the intention to consent to organ donation: a questionnaire survey, Transplantation Proceedings 38 (2006), pp. 2756-2760.

[36] R. Arnold, S. Bartlett, J. Bernat, J. Colonna, D. Dafoe and N. Dubler et al., Financial incentives for cadaver organ donation: an ethical reappraisal, Transplantation 73 (8) (2002), pp. 1361-1367.

[37] M.C. Oz, A.R. Kherani, A. Rowe, L. Roels, C. Crandall and L. Tomatis et al., How to improve organ donation: results of the ISHLT/FACT poll, Journal of Heart and Lung Transplantation 22 (4) (2003), pp. 389-410.

[38] M. Schweda and S. Schiktanz, Public ideas and values concerning the commercialization of organ donation in four European countries, Social Science and Medicine 68 (6) (2009), pp. 1129-1136.

[39] J.D. Jasper, C.A.E. Nickerson, J.C. Hershey and D.A. Asch, The public's attitudes toward incentives for organ donation, Transplantation Proceedings 31 (1999), pp. 2181-2184.

[40] W.Fv. Raaij and M. Taels, Effectiviteit van systemen en prikkels: Beslissystemen, beloningen en orgaandonatie (Effectiveness of systems and incentives: consent systems, financials rewards, and organ donation). In: Coördinatiegroep Orgaandonatie, Editor, Masterplan orgaan donatie: de vrijblijvendheid voorbij (Masterplan organ donation: beyond volunteerism), Coördinatiegroep Orgaandonatie, Den Haag (2008).

[41] J. Gevers, A. Janssen and R. Friele, Consent systems for post mortem organ donation in Europe, European Journal of Health Law 11 (2) (2004), pp. 175-186.

[42] F. Murphy, D. Cochran and S. Thornton, Impact of a Bereavement and Donation Service incorporating mandatory 'required referral' on organ donation rates: a model for the implementation of the Organ Donation Taskforce's recommendations, Anaesthesia 64 (2009), pp. 822-828.

[43] A. Abadie and S. Gay, The impact of presumed consent legislation on cadaveric organ donation: a cross-country study, Journal of Health Economics 25 (2006), pp. 599-620.

[44] R. Coppen, R.D. Friele, R.L. Marquet and J.K.M. Gevers, Opting-out systems: no guarantee for higher donation rates, Transplant International 18 (2005), pp. 1275-1279.

[45] R. Coppen, R.D. Friele, J.K.M. Gevers, G.A. Blok and Jvd. Zee, The impact of donor policies in Europe: a steady increase, but not everywhere, BMC Health Services Research 8 (1) (2008), p. 235.

[46] R.W. Gimbel, M.A. Strosberg, S.E. Lehrman, E. Gefenas and F. Taft, Presumed consent and other predictors of cadaveric organ donation in Europe, Progress in Transplantation 13 (1) (2003), pp. 17-23.

[47] E.J. Johnson and D. Goldstein, Medicine: do defaults save lives?, Science 302 (2003), pp. 1338-1339.

[48] R. Matesanz, Cadaveric organ donation: comparison of legislation in various countries of Europe, Nephrology Dialysis Transplantation 13 (1998), pp. 1632-1635.

[49] R. Matesanz, Factors that influence the development of an organ donation program, Transplantation Proceedings 36 (2004), pp. 739-741.

[50] E. Mossialos, J. Costa-Font and C. Rudisill, Does organ donation legislation affect individuals' willingness to donate their own or their relative's organs? Evidence from European Union survey data, BMC Health Services Research 8 (1) (2008), p. 48 
Coppen, R., Friele, R.D., Zee, J. van der, Gevers, S.K. The potential of legislation on organ donation to increase the supply of donor organs. Health Policy: 2010, 98(2-3), 164-170

[51] L. Wright, Is presumed consent the answer to organ shortages? No, British Medical Journal 334 (2007), p. 1089

. [52] A. Janssen and J. Gevers, Explicit or presumed consent and organ donation post-mortem: does it matter?, Medicine and Law 24 (2005), pp. 575-583. 


\section{BOX 1: THE PROVISIONS OF THE DUTCH ORGAN DONATION ACT}

\section{Provisions to codify the law and to provide legal certainty}

The primary reason why legislation was adopted was to safeguard the rights of (potential) donors, e.g. the fundamental right to protection of physical integrity (art. 1.3 of the Declaration on the Promotion of patients' rights (the Declaration), art. 1 of The Convention). An important element of legislation on organ donation is the consent system. In an explicit consent system the donor himself has to authorize organ removal after his death. In The Netherlands, if the deceased's will is not known, the next of kin are consulted. By contrast, a strict presumed consent system does not require obtaining consent - either from the deceased, or from the next of kin; it is sufficient to verify that the deceased did not object during his lifetime to becoming a donor [17]. Although the international standards for organ donation support both explicit and presumed consent systems, most European countries have implemented a presumed consent system. According to the Dutch government an explicit consent system is more in line with the assumption that becoming a donor should not be the choice of government but of the individual (or his/her next of kin). Also, it was not expected that a presumed consent system would lead to more organ donations than an explicit consent system.

The Dutch system is regarded as an explicit consent system because consent, either from the donor or from his next of kin, is necessary; the removal of organs only takes place after consent (section 9(1) and in section 11(1) of the Act).

Consent for post-mortem donation can be given prior to death by means of a document such as a donor card, by registering consent in the National Donor Register or by means of a last will. It is also possible to register one's refusal, to register a wish to leave the decision to relatives or to some other, specified individual, or to register consent to be a donor of all but certain organs and/or tissues. Other countries likewise provide for registration of consent as well as refusal [17].

The government considered that offering citizens the opportunity to register would increase their trust in organ procurement. Consequently, this increase in trust was expected to contribute to an increase in the supply of donor organs.

Besides the implementation of the consent system, the Act contains other provisions for safeguarding the rights of (potential) donors. For example, according to the Act organs may only be procured when the potential donor has been declared brain death by a physician following the procedures of the National Health Council's brain death protocol (version of 2006) [18] (section 15). Recently, in the USA a discussion has been raised on the compliance of brain death with the legal definition of death [19] and [20]. In The Netherlands death is not defined by law; according to Dutch legislation, an individual is dead when he is declared brain death according to the brain death protocol. The advantage of this protocol is that it can be changed over time and can be adjusted to new medical, legal and ethical insights. Since 1973, the National Health Council has given its advice on brain death seven times.

Furthermore, physicians have to follow certain procedures for preparatory activities and the preservation of organs (section 22) and the physician who is involved in the determination of the death of the donor is not allowed to be involved in the removal or transplantation of the donor's organs (section 14).

\section{Provisions to increase the supply of donor organs and tissues}

The objective to increase the supply of donor organs and tissues is related to basic social rights, in particular the right to health care (section 22 of the Dutch Constitution). For patients whose organs are failing, transplantation is often the only available treatment. The consent system was considered to be the most important provision for creating trust in the procurement system and for increasing the supply of donor organs. Apart from the consent system two other provisions with this same function were enacted:

- Protocol in hospitals (to ensure that medical professionals in hospitals put effort into the procurement of post-mortem organs; section 23);

- Legal basis for preparatory activities and preservation of organs (section 22).

\section{Provisions to ensure the fair allocation of donor organs and tissues}

The right to health care also presupposes equitable access to and equal availability of care [8]. Therefore, the Act contains provisions for the allocation of organs.

The allocation of organs takes place on both national and international level and is only based on medical criteria and waiting time on the national transplant waiting list (section 18(3)). Which medical criteria are relevant varies between organ types and is established on a national level by medical professionals. 
In The Netherlands, the Dutch Transplant Foundation (NTS) documents the relevant (medical) characteristics of patients who are on the national organ donation waiting list. The NTS shares this information with the Eurotransplant International Foundation (Eurotransplant). Eurotransplant is responsible for the mediation and allocation of organ donation procedures in Austria, Belgium, Croatia, Germany, Luxemburg, The Netherlands and Slovenia. The NTS is responsible for the allocation of organs in The Netherlands.

\section{Provisions to prevent commercialisation and organ trade}

The fourth objective of the Act reflects the more general principle of human dignity and the noncommerciality principle in health care. To protect human dignity and prevent organ trade and commercialisation, the legislator stipulated that the donation of organs may only take place on a voluntary basis; remuneration of donors (or their family) is not allowed, nor are other parties in the process allowed to make profit out of the donation of organs. Certain payments are not to be treated as financial gain such as expenses that may be incurred during or as a result of the donation of organs (section 2). Only a not-forprofit organ centre (sections 24-25), which is licensed by the minister, is allowed to allocate organs. 